\title{
Leaf area and tree increment dynamics on a fertile mixed-conifer site in southern Finland
}

\author{
Kevin L. O’Hara*, Erkki Lähde, Olavi Laiho, Yrjö Norokorpi, Timo Saksa \\ Finnish Forest Research Institute, Parkano Research Station, Kaironiementie 54, 39700 Parkano, Finland
}

(Received 3 March 1998; accepted 16 June 1998)

\begin{abstract}
Ratios of volume increment to photosynthetic area were used to provide measures of growing space efficiency in Scots pine (Pinus sylvestris L.) and Norway spruce (Picea abies (L.) Karst.) dominated stands on a productive site in southern Finland. Eight plots were established in a stand treatment study and three plots in nearby untreated Scots pine stands. Treatments included low thinnings, individual tree selection cuttings and untreated controls. Projected leaf area of individual trees was represented by sapwood cross-sectional area at the crown base. Ratios of volume increment to leaf area index (LAI) for stands and species, and ratios of volume increment to sapwood cross-sectional area were used to assess the relative growing space efficiency of stand components. LAI was greatest in stands dominated by Norway spruce. Strong relationships were observed between individual tree volume increment and sapwood area of both Scots pine and Norway spruce. For both species, these relationships were improved when developed separately for lower and upper crown classes. (C Inra/Elsevier, Paris.)
\end{abstract}

Picea abies / Pinus sylvestris / leaf area index / crown efficiency / mixed species

Résumé - Surface foliaire et dynamique d'accroissement des arbres dans des peuplements mélangés de conifères, dans une station fertile de Finlande méridionale. Les rapports entre l'accroissement en volume et les surfaces photosynthétiques ont été utilisés pour mesurer l'efficacité de l'espace disponible pour la croissance des arbres dans des peuplements mélangés de pin sylvestre (Pinus sylvestris L.) et d'épicéa commun dans une station fertile de Finlande méridionale. Huit placettes ont été établies dans les peuplements étudiés ainsi que trois placettes à proximité dans un peuplement de pin sylvestre. Des éclaircies par le bas, des coupes de sélections d'arbres individuels et des témoins non traités étaient pris en compte dans cette étude. L'indice foliaire des arbres individuels était représenté par la surface de la section transversale du bois d'aubier à la base de la cime. Les rapports entre l'accroissement en volume et l'indice foliaire pour les peuplements et les espèces, et les rapports entre l'accroissement en volume et la surface de la section transversale du bois d'aubier ont été utilisés pour évaluer l'efficacité relative de l'espace d'accroissement des composantes des peuplements. L'indice foliaire était le plus élevé dans les peuplements dominés par l'épicéa commun. De bonnes relations entre l'accroissement en volume d'arbres individuels et la surface de l'aubier du pin sylvestre et des épicéas ont été observées. Pour les deux espèces, ces relations ont améliorées en séparant les classes de cimes supérieures des classes inférieures. (C Inra/Elsevier, Paris.)

Picea abies / Pinus sylvestris / indice foliaire / efficacité des couronnes / essences mélangées

\section{INTRODUCTION}

Leaf area index (LAI), or the ratio of projected foliage area to ground surface area, provides a useful measure of forest site utilisation, particularly in lightlimited environments. The amount of foliage generally increases during even-aged stand development to reach a maximum steady-state level that is related to site

* Correspondence and reprints: 145 Mulford Hall \# 3114, University of California, Berkeley, CA 94720-3114, USA; ohara@nature.berkeley.edu 
quality $[12,16,33]$. Leaf area index can also be interpreted as a representation of occupied growing space $[19,21]$. For stands at less than the maximum or potential LAI, some growing space can be assumed to be unused. The ratio of occupied or actual LAI to potential LAI therefore provides a measure of relative site utilisation. For a stand which received a thinning treatment, the reduction in density is used to reallocate LAl or growing space to fewer trees. The initial result will be a lower level of growing space occupancy. Stand volume increment may be substantially lower following the treatment if the reduction in growing space occupancy is great.

However, the reduction in volume increment is difficult to predict from only LAI because of variations in productivity of leaf area in different parts of the stand. For example, crown classes in even-aged stands will typically have different ratios of tree increment to leaf area with codominants generally the highest $[4,19]$. These ratios of tree increment to leaf area can be interpreted as 'growing space efficiencies' (GSEs) [19]. Various combinations or structures of trees with different GSEs can have different productivities in both thinned and unthinned stands even when total growing space occupancy is constant [20].

These differences in GSE between trees in different crown positions present opportunities for manipulation of stand structures to enhance stand productivity. Concepts related to growing space or leaf area efficiency are relatively new and are not integrated into stand management procedures. However, the strong relationships between tree growth and tree leaf area indicate that there is potential for researchers to develop stand management procedures once the dynamics of leaf area and tree growth are known.

Mixed-species stands present an additional complication over single-species stands. A more shade tolerant species will support greater amounts of foliage over a longer average crown depth than a less tolerant species. The adaptation of the more tolerant species to photosynthesize over a range in canopy depth results in a reduction in total photosynthesis efficiency that is compensated by the larger photosynthetic capacity or leaf area of the tree. Hence comparisons of the growing space efficiency of a tolerant and intolerant tree are difficult.

Few studies have examined leaf area dynamics in mixed conifer stands. Schroeder et al. [29] found increasing volume increment with increasing LAI in mixed conifer stands in several distinct environments in the interior Pacific Northwest of North America. However, no information on individual productivity by species was provided. Smith and Long [30] examined the relative contributions of lodgepole pine (Pinus contorta var. latifolia Dougl.) and subalpine fir (Abies lasio- carpa Hook (Nutt.)) in mixed stands in the central Rocky Mountains of North America. LAIs and relative shade tolerance were higher for pure subalpine fir than for lodgepole pine. Mixed stands were of intermediate LAI. Stand volume increment decreased as the percentage of lodgepole pine increased, and no synergistic effects of the mixed species interaction were observed [30]. As a European application, this paper presents results from a leaf area study in Scots pine (Pinus sylvestris L.) and Norway spruce (Picea abies (L.) Karst.) dominated forests in southern Finland. The objectives were to examine patterns of growing space efficiency from the stand (plot), species and tree level to develop a preliminary stand-level stocking allocation model for silviculture selection in a related study.

\section{MATERIALS AND METHODS}

\subsection{Study area}

Individual treatment blocks within the Vessari stand treatment study area in Vilppula Research Forest in southern Finland $\left(62^{\circ} 3^{\prime} \mathrm{N}, 24^{\circ} 15^{\prime} \mathrm{E}\right)$ were selected for analysis. The Vessari study is examining the effects of different cutting treatments on the development and increment of Norway spruce dominated mixtures of Scots pine, silver birch (Betula pendula Roth.), pubescent birch (B. pubescens Ehrh.), and other broadleaf species. The study area was regenerated in the late $1940 \mathrm{~s}$ using a seed-tree method. The seed trees (Scots pine) were removed in 1960-1961 and most of the sapling stand cleaned. The Vessari study area has previously been described by Lähde [9]. Treatment blocks at Vessari were established in a grid and treatments were randomized across the study area. Blocks were square and 0.25 ha in size. Treatments implemented in 1986 over entire blocks included low thinning ( 25 blocks), single-tree selection ( 15 blocks), dimension cutting (cutting trees greater than $9 \mathrm{~cm} \mathrm{dbh}$; four blocks), and untreated controls (seven blocks). Density levels were also varied in each treatment. In 1994, some blocks received a second similar treatment which further adjusted treatment densities.

For the present study, eight treatment blocks were selected for additional study. These blocks included two from each of the untreated control, and single-tree selection treatments, and four plots from the low thinning treatments. These four low thinning treatments included two treated in 1986 and 1994, and two that were treated only in 1986. Tree species composition varied from nearly pure Norway spruce to conifer-broadleaf mixtures. Specific plots within treatments were selected to 
minimize the broadleaf component and maximize the percentage of Scots pine.

Three additional plots were established in nearby stands of predominantly Scots pine with lesser amounts of Norway spruce and broadleaf species (table I). The youngest stand (plot B) originated from a seed-tree cut in 1972/73. Plot A was a plantation originating in 1968. The oldest stand (plot $\mathrm{C}$ ) included dominant trees of natural origin and approximately 80 years of age at breast height.

Plots treated with low thinning averaged a 14-year age variation at breast height (table I). Their stem diameter distribution was bell-shaped with a fairly wide range exceeding $20 \mathrm{~cm}$. Control plot 54 was very similar in structure but denser and with greater volume. Selection plots and the other control had a reverse-J (regularly allsized) stem distribution, more variation in age and undergrowth smaller than $6 \mathrm{~cm}$. All pine stands had vigorous Norway spruce undergrowth. The pine overstory was even-aged (within-stand variation: 8 years) and even-sized (within-stand variation: $12 \mathrm{~cm}$ ).

All sites were generally within the transition between Myrtillus and Oxalis-Myrtillus site types [3]. Site index fluctuated between 27 and $33 \mathrm{~m}$ for Scots pine and from 28 to greater than $33 \mathrm{~m}$ for Norway spruce (100 year base) [5] across all sites.

\subsection{Sampling methods}

Destructive sampling and tree boring were not permitted within the 0.03 -ha permanent plots established in the middle of the square treatment blocks at Vessari. Therefore, quarter-circle measurement plots were established in 1996 within the treatment blocks but outside the circular permanent plots (figure 1). Quarter-circle plots had a radius of $9.8 \mathrm{~m}$ (0.0075 ha) and were centred $22 \mathrm{~m}$ from the permanent plot centre along the diagonals within the treatment block. The number of quarter-circle plots established varied with treatment density. In treatments with high densities, a single quarter-circle plot which included 50-60 trees (6 500-8 000 trees/ha) was established. In the low thinning treatment blocks, which had lower densities, two or three quarter-circle plots were established to sample approximately $20-30$ total trees/treatment. Quarter-circle plots were combined within a treatment block to form total treatment plot sizes that varied with treatment (table I). Plot corners were subjectively chosen for establishment of quartercircle plots in order to minimize the number of broadleaf trees and to maximize the number of Scots pine trees included. For the even-aged Scots pine plots, identical tree measurement procedures were used. However, sam-

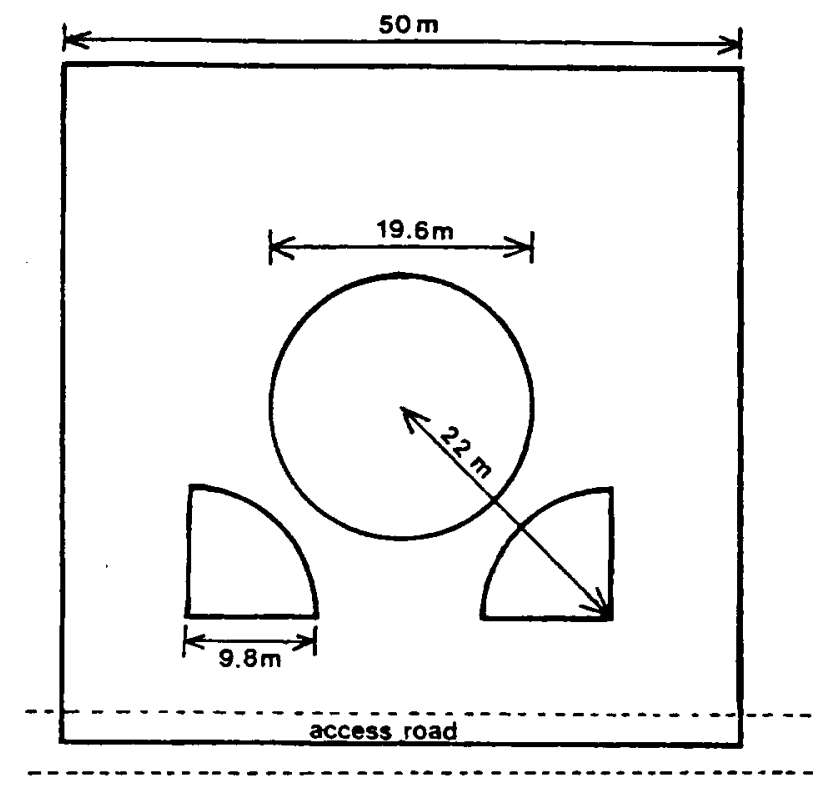

Figure 1. Map of 0.25-ha square treatment block showing permanent 0.03 -ha circular plot and two 0.0075 -ha quarter-circle destructive sampling plots used in the present study. Numbers of quarter-circle plots varied with plot density. The permanent plots were not used because tree boring and destructive sampling were not permitted.

ple plots were circular and sizes varied depending on the density of the stand ranging from 0.03 to 0.01 ha (table I).

All trees exceeding approximately $2 \mathrm{~cm}$ in diameter at breast height were measured in early September 1996. Many smaller Norway spruce trees were also present. Trees greater than approximately $5 \mathrm{~cm}$ in diameter at $1.3 \mathrm{~m}$ were measured in the field by taking two diameter measurements at $90^{\circ}$ apart (with a calliper to the nearest $\mathrm{mm}$ ), bark thickness on the north and east sides (with a bark thickness gauge to the nearest $0.5 \mathrm{~mm}$ ), total height and height to the base of the live crown (with a Haglöf Forestor Vertex hypsometer to the nearest $\mathrm{dm}$ ). Trees greater than $10 \mathrm{~cm}$ in diameter were also cored on the north and east sides and the sapwood/heartwood boundary marked on the core in the field. Trees between 5 and $10 \mathrm{~cm}$ in diameter were cored once. Sapwood thickness (nearest $0.1 \mathrm{~mm}$ ), 5-year radial growth (with a ring counter to the nearest $0.01 \mathrm{~mm}$ ), and tree age were later measured on these cores in the laboratory. The social class group of each tree was assigned in the field: dominant and codominant trees were assigned to the 
Table I. Characteristics of sample plots.

\begin{tabular}{|c|c|c|c|c|c|c|c|c|c|c|c|c|c|c|}
\hline \multirow[b]{2}{*}{ Treatment } & \multirow[b]{2}{*}{ Plot } & \multirow{2}{*}{$\begin{array}{l}\text { Measured } \\
\text { plot area } \\
\text { (ha) }\end{array}$} & \multirow{2}{*}{$\begin{array}{l}\mathrm{BH} \\
\text { Age } \\
\text { (a) }\end{array}$} & \multirow{2}{*}{$\begin{array}{l}\text { Density } \\
\text { (trees/ha) }\end{array}$} & \multicolumn{3}{|c|}{$\begin{array}{c}\text { Density by species } \\
\text { (trees/plot) }\end{array}$} & \multirow{2}{*}{ Min. } & \multirow{2}{*}{$\begin{array}{c}\text { Diameter } \\
X \\
(\mathrm{~cm})\end{array}$} & \multirow[t]{2}{*}{ Max. } & \multirow{2}{*}{$\begin{array}{c}\text { Mean } \\
\text { basal area } \\
\left(\mathrm{m}^{2} \mathrm{ha}^{-1}\right)\end{array}$} & \multicolumn{3}{|c|}{$\begin{array}{c}\text { Basal area by } \\
\text { species }\left(\mathrm{m}^{2} \mathrm{ha}^{-1}\right)\end{array}$} \\
\hline & & & & & SP & $N S$ & BL & & & & & $\mathrm{SP}$ & NS & $\mathrm{BL}$ \\
\hline Low thin & 19 & 0.0225 & $28-37$ & 1,200 & 9 & 18 & 0 & 8.9 & 17.1 & 22.9 & 27.5 & 13.6 & 13.9 & 0 \\
\hline Low thin ${ }^{2}$ & 38 & 0.0225 & $14-41$ & 1,378 & 3 & 20 & 8 & 6.4 & 16.2 & 23.3 & 28.3 & 3.7 & 18.8 & 5.8 \\
\hline Low thin? & 6 & 0.015 & $25-38$ & 1,600 & 2 & 17 & 5 & 8.1 & 14.8 & 23.0 & 27.6 & 1.6 & 20.9 & 5.1 \\
\hline Control $^{3}$ & 54 & 0.0075 & $28-41$ & 3,467 & 1 & 24 & 1 & 8.2 & 12.3 & 20.7 & 41.2 & 1.4 & 38.3 & 1.4 \\
\hline Control & 34 & 0.0075 & $15-40$ & 7,067 & 1 & 42 & 10 & 2.5 & 9.1 & 22.8 & 45.9 & 5.4 & 28.4 & 12.1 \\
\hline Untreated & A & 0.02 & $8-26$ & 2,850 & 32 & 24 & 1 & 1.0 & 11.0 & 18.8 & 26.9 & 22.6 & 3.4 & 0.9 \\
\hline Untreated & B & 0.01 & $6-17$ & 5,700 & 47 & 9 & 1 & 1.9 & 9.1 & 17.2 & 36.8 & 36.4 & 0.4 & 0.1 \\
\hline Untreated & $\mathrm{C}$ & 0.03 & $8-81$ & 1,733 & 19 & 28 & 5 & 2.3 & 17.7 & 32.2 & 42.7 & 35.4 & 7.2 & 0.1 \\
\hline
\end{tabular}

Numbered plots are those from the Vessari stand treatment study area. Plots A through $\mathrm{C}$ were supplemental plots added to increase the representation of Scots pine in the study. Basal area totals for species may not add to plot totals because of rounding. $\mathrm{BH}=$ breast height, $\mathrm{SP}=\mathrm{Scots}$ pine, NS $=$ Norway spruce, $\mathrm{BL}=$ broadleaf species, $\mathrm{X}=$ quadratic mean diameter.

${ }^{1}$ Plot thinned in 1986 and $1994:{ }^{2}$ plot thinned in 1986 only: ${ }^{3}$ plot received a cleaning treatment in 1961.

overstory class group and intermediate and suppressed trees to the understory class group.

Trees less than approximately $5 \mathrm{~cm}$ in diameter were felled and their total height and height to base of live crown were measured. A disk of $5-10 \mathrm{~mm}$ thick was removed from the stem of each tree at $1.3 \mathrm{~m}$. The sapwood/heartwood boundary was marked on each disk in the field and disks were removed to the laboratory for measurement of diameter, bark thickness, sapwood thickness, 5-year radial increment and tree age.

Representative Norway spruce trees from each treatment and crown class were felled and thin stem disks were removed from the base, $1.3 \mathrm{~m}$, and from the base of the live crown. A total of 14 trees were sampled. These trees were used to estimate sapwood taper of Norway spruce between $1.3 \mathrm{~m}$ and crown base. The sapwood/heartwood boundary was marked on each disk in the field and disks were removed to the laboratory for measurement of bark, sapwood thickness and tree age.

Five-year height growth was determined by measuring the height to the fifth branch whorl from the top. A representative subsample of Scots pine and Norway spruce trees were selected over all treatments and ages. The height growth subsample included some trees less than $5 \mathrm{~cm}$ in diameter that were destructively sampled and all trees in the Norway spruce sapwood taper subsample. Height growth on the remainder of the height growth subsample was measured on standing trees with the Vertex hypsometer to the nearest $\mathrm{dm}$. The total sub- sample included 64 Norway spruce and 42 Scots pine or 24 and $34 \%$, respectively, of the total trees sampled for each of these species.

\subsection{Volume estimation}

Cubic stem volume was estimated for individual trees as a function of height and diameter using equations developed by Laasasenaho [8]. Volume of broadleaf species other than birch (e.g. aspen (Populus tremula L.) or rowan (Sorbus aucuparia L.)) was estimated with Laasasenaho's equation for birch. Volume was also estimated for all trees 5 years previous to the 1996 measurements of this study. Five-year radial increment was measured on each increment core or disk and averaged for trees where more than one measurement was taken. Bark thickness was assumed to have increased over the previous 5 years at the same rate as diameter increment. Height increment of the remaining trees was estimated from trees where height increment was measured using linear regression equations. For Scots pine, 5-year height increment (HI) was estimated using tree basal area (BA), and sapwood area at crown base (SACB) as independent variables $(\mathrm{HI}=14.898-0.043 \times \mathrm{BA}+1.165 \times \mathrm{SACB}$; $\left.\mathrm{R}^{2}=0.59, \mathrm{~S}_{\mathrm{ylx}}=4.2 \mathrm{dm}, n=42\right)$. For Norway spruce, height $(\mathrm{H})$, tree basal area and sapwood area at crown base were independent variables $(\mathrm{HI}=0.870-0.075 \times$ $\mathrm{BA}+0.047 \times \mathrm{H}+0.816 \times \mathrm{SACB}^{0.738} ; \mathrm{R}^{2}=0.76$, 
$\mathrm{S}_{\mathrm{ylx}}=4.0 \mathrm{dm}, n=64$ ). Broadleaf trees were assumed to increase in height growth at the same rate as Norway spruce. Five-year volume increment was the difference between measurements in 1996 and estimated volumes 5 years before. Plot volume increment was the sum of individual tree volume increment.

\subsection{Leaf area estimation}

Heartwood cross-sectional radius was calculated as the average difference between diameter inside bark and the sapwood radius from the two measurements per tree and converted to cross-sectional area. Sapwood crosssectional area was the difference between basal area inside bark and heartwood area.

Crown base sapwood area was estimated for Norway spruce trees using equations developed in this study with sapwood basal area at $1.3 \mathrm{~m}(\mathrm{SABH})$ and crown base height (HCB) as independent variables (SACB $\left(\mathrm{cm}^{2}\right)=3.088 \times \mathrm{SABH}^{0.76}-0.382 \times \mathrm{HCB} ; \mathrm{R}^{2}=0.98$, $\left.\mathrm{S}_{\mathrm{y} \mid \mathrm{x}}=14.4 \mathrm{~cm}^{2}, n=14\right)$. These sapwood taper relationships were also used on all broadleaf species in this study. For Scots pine, sapwood at crown base was estimated from diameter at $1.3 \mathrm{~m}$, sapwood diameter at $1.2 \mathrm{~m}$, tree height and height to crown base with relationships described by Ojansuu and Maltamo [23]. Projected leaf areas of individual trees were estimated using ratios of leaf area $\left(\mathrm{m}^{2}\right)$ : sapwood cross-sectional area $\left(\mathrm{cm}^{2}\right)$ at crown base. For Norway spruce, a ratio of 0.422 $\left(\mathrm{m}^{2} / \mathrm{cm}^{2}\right)$ developed in Germany was used [24]. For Scots pine, a ratio of $0.129\left(\mathrm{~m}^{2} / \mathrm{cm}^{2}\right)$ from southern Finland was used [13]. Leaf areas of all broadleaf species were calculated using a ratio of $0.183\left(\mathrm{~m}^{2} / \mathrm{cm}^{2}\right)$ developed for Betula papyrifera (Marsh) in eastern Canada (as the average of the four values reported by Pothier and Margolis [26].
Some studies have indicated that leaf area/sapwood relationships are site specific and affected by stand treatment histories while other studies have found only minor effects of these factors [14]. There is also some evidence that leaf area/sapwood relations can vary over the geographic range of a species $[15,22]$. Ideally site specific relations would be developed for individual study areas to insure site specificity. In this study, the most local equations available in the literature were used for estimation of stand level (treatment) LAIs. Because the leaf area/sapwood cross-sectional area relation is nearly always assumed to be linear, individual tree analyses used sapwood cross-sectional area at crown base without converting to leaf area. O'Hara [19] previously used sapwood cross-sectional area as the independent variable in a study of productivity in coast Douglas fir (Pseudotsuga menziesii var. menziesii (Mirb.) Franco)

\section{RESULTS}

\subsection{Stand-level dynamics}

Total standing volume of the Vessari stand treatment plots ranged from 234 to $336 \mathrm{~m}^{3} \mathrm{ha}^{-1}$ (table $I I$ ). The greatest volume was in plot 54 which received only a cleaning treatment in 1961. The four low thinning plots had the lowest volume which averaged $238 \mathrm{~m}^{3} \mathrm{ha}^{-1}$. Volume on the three supplemental Scots pine plots (plots A-C) was representative of their age and stocking; however, the lowest standing volume was in plot A which originated by artificial regeneration. Volume increment of the Vessari stand treatment study plots ranged from 11.3 to $14.4 \mathrm{~m}^{3} \mathrm{ha}^{-1} \mathrm{a}^{-1}$ over the past 5 years not including mortality or thinning removal (table II). Plots with

Table II. Stand volume, average annual volume increment over previous 5 years and leaf area index (LAI) of sample plots.

\begin{tabular}{|c|c|c|c|c|c|c|c|c|c|c|c|}
\hline \multirow[b]{2}{*}{ Treatment } & \multirow[b]{2}{*}{ Plot } & \multirow{2}{*}{$\begin{array}{c}\text { Stand } \\
\text { volume } \\
\left(\mathrm{m}^{3} \mathrm{ha}^{-1}\right)\end{array}$} & \multirow{2}{*}{$\begin{array}{c}\text { Volume } \\
\text { increment } \\
\left(\mathrm{m}^{3} \mathrm{ha}^{-1} \mathrm{a}^{-1}\right)\end{array}$} & \multirow{2}{*}{$\begin{array}{c}\text { Stand } \\
\text { LAI } \\
\left(\mathrm{m}^{2} \mathrm{~m}^{-2}\right)\end{array}$} & \multirow{2}{*}{$\begin{array}{c}\text { Stand } \\
\text { efficiency } \\
\left(\mathrm{m}^{3} \mathrm{~m}^{-2}\right)\end{array}$} & \multicolumn{3}{|c|}{$\begin{array}{l}\text { LAI by species } \\
\qquad\left(\mathrm{m}^{2} \mathrm{~m}^{-2}\right)\end{array}$} & \multicolumn{3}{|c|}{$\begin{array}{c}\text { Stand efficiency } \\
\text { by species }\left(\mathrm{m}^{3} \mathrm{~m}^{-2}\right)\end{array}$} \\
\hline & & & & & & SP & NS & $\mathrm{BL}$ & SP & NS & $\mathrm{BL}$ \\
\hline Low thin & 19 & 235 & 12.8 & 3.7 & 3.4 & 0.6 & 3.2 & 0 & 10.2 & 2.2 & - \\
\hline Low thin & 38 & 240 & 11.6 & 4.7 & 2.5 & 0.1 & 3.8 & 0.8 & 8.7 & 2.1 & 2.9 \\
\hline Low thin & 6 & 234 & 12.7 & 5.7 & 2.2 & 0.1 & 4.8 & 0.8 & 8.4 & 2.0 & 3.3 \\
\hline Control & 54 & 336 & 11.3 & 6.1 & 1.9 & $<0.1$ & 5.8 & 0.2 & 7.7 & 1.8 & 2.6 \\
\hline Control & 34 & 329 & 14.4 & 7.3 & 2.0 & 0.3 & 5.3 & 1.8 & 9.1 & 1.4 & 2.4 \\
\hline Untreated & $\mathrm{A}$ & 172 & 10.1 & 2.4 & 4.2 & 1.2 & 1.1 & 0.1 & 6.8 & 1.4 & 3.2 \\
\hline Untreated & B & 190 & 17.1 & 2.6 & 6.6 & 2.5 & 0.1 & $<0.1$ & 6.8 & 1.5 & 1.5 \\
\hline Untreated & $\mathrm{C}$ & 518 & 8.9 & 2.0 & 4.4 & 0.9 & 1.1 & $<0.1$ & 7.9 & 1.5 & 0.9 \\
\hline
\end{tabular}

LAI totals by species may not add to plot totals because of rounding. SP $=$ Scots pine, NS $=$ Norway spruce, $\mathrm{BL}=$ broadleaf species. 
the highest number of trees per ha (table I) had the highest increment. In the three supplemental plots, increment covered a much greater range than the Vessari plots and was highest in plot B. Plot $\mathrm{C}$ had long ago passed its growth culmination.

LAI totals were highest in plots with higher proportions of Norway spruce relative to Scots pine or broadleaf species and in plots with higher stocking (table II). Plots 5 and 34 had large amounts of both Norway spruce and broadleaf species, minimal amounts of Scots pine and had LAIs over 7.0. The lowest LAIs were in those plots with the greatest proportion of Scots pine (plots A, B and C) or plots which had received low thinning treatments.

A weak relationship was apparent between average annual volume increment and LAI, and between volume increment and treatment among the Vessari plots or the three supplemental plots (figure 2, table II). The highest volume increment of the Vessari plots was observed in the two plots with the highest LAI (plots 5 and 34). However, the other control and selection treatment plots (54 and 36) had among the lowest volume increment of any plot at Vessari despite having relatively high LAI. Although the low thinning treatments had a volume increment that was among the lowest of the Vessari plots, the lowest was actually the control treatment which received a cleaning treatment in 1961 (plot 54). Supplemental plot B had the highest increment of the entire study.

The ratio of stand volume increment to LAI, used as a measure of growing space efficiency or stand efficiency [21, 34], declined with increasing LAI (figure 3). Higher stand efficiencies were found in plots with higher proportions of Scots pine to Norway spruce (table II). A combination of plot LAI and distribution of LAI among species appeared to be more closely related to volume increment than treatment type. For example, total LAI was low in plots A, B, C, 19 and 21 because Scots pine represented a large segment of the stocking (table I).

\subsection{Species and social class dynamics}

Growing space efficiency can also be determined for individual species as the ratio of species increment to species LAI for each plot. These ratios indicate Scots pine leaf area was relatively efficient at producing volume increment relative to Norway spruce or the broadleaf species (table II). Plots with high proportions of Scots pine were therefore relatively efficient compared to plots which had little or no Scots pine. However, the highest plot volume increments occurred where stand efficiency was relatively low (e.g. plots 5

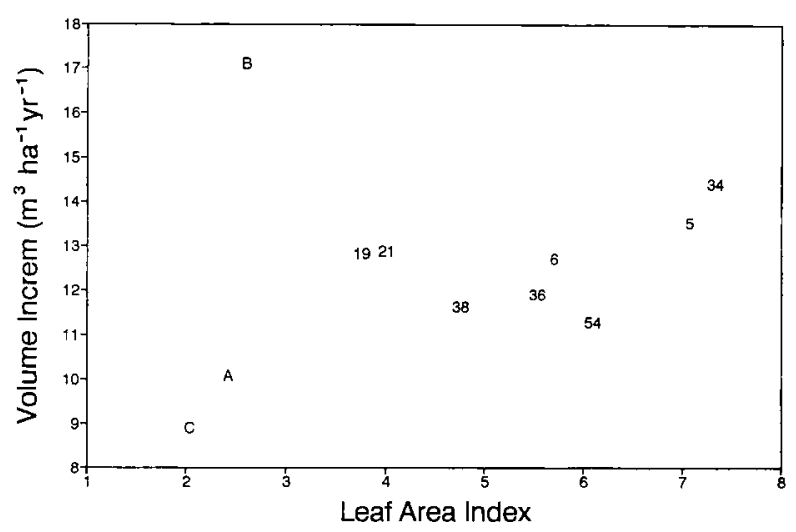

Figure 2. Average annual plot volume increment and LAI of the plots indicated by plot number.

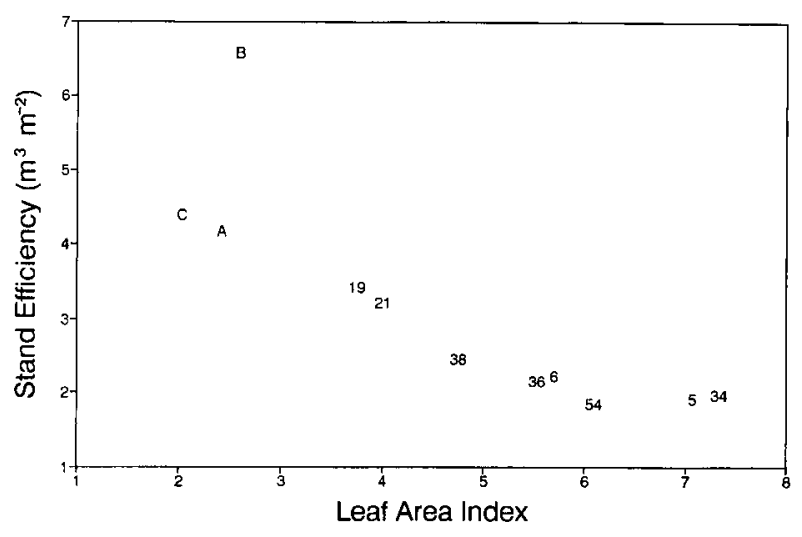

Figure 3. Stand efficiency (stand volume increment per unit LAI) over LAI for the 11 treatment plots indicated by plot number.

and 34) because these plots had relatively large amounts of Norway spruce and broadleaf LAI.

The overstory generally had higher LAIs than the understory (figure $4 A$ ). Exceptions to this trend were the Vessari control plots and one selection plot (5) where total LAI in the overstory and understory were more comparable. All the low thinning treatments had very litthe LAI in the understory. Increment was highest in plots with higher proportions of Scots pine LAI (figure $4 B$ ). 

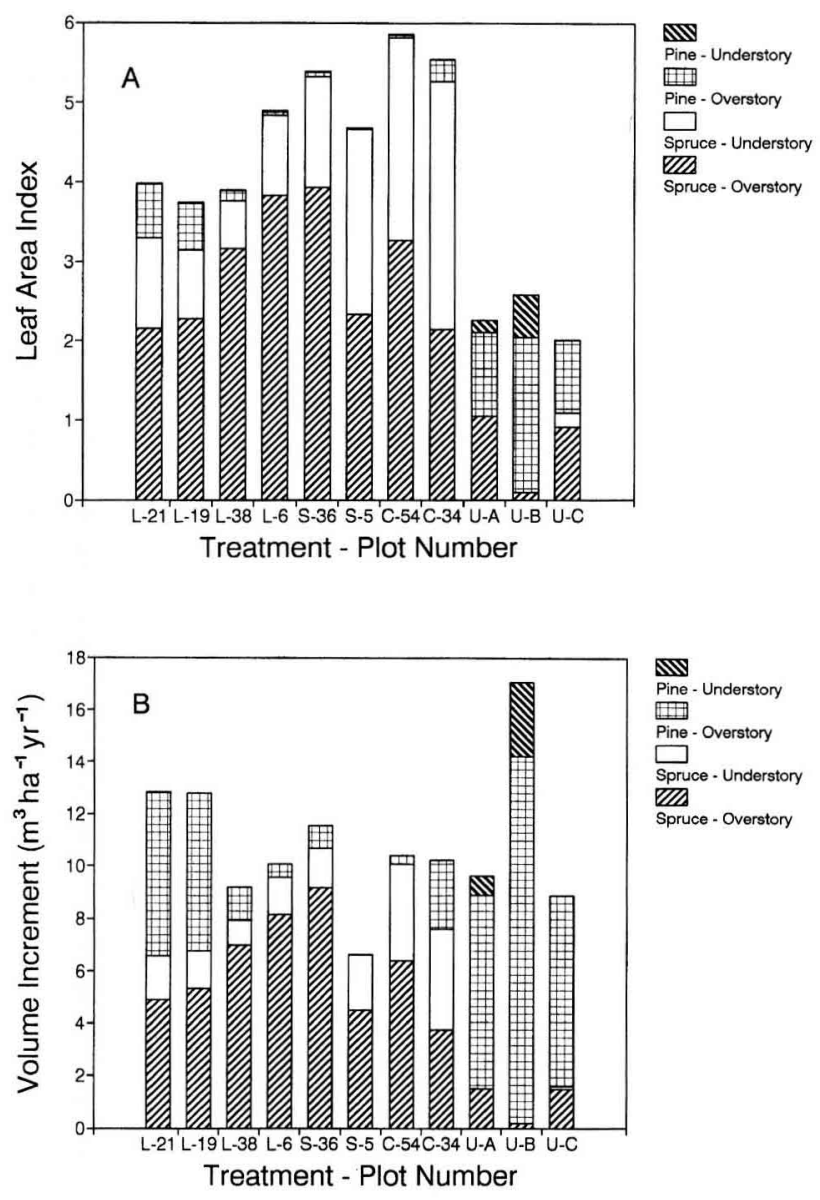

Figure 4. Leaf area index (A), and volume increment (B) by treatment - plot number, species and crown class group. Treatment designations: $\mathrm{U}=$ supplemental Scots pine plots, $\mathrm{S}=$ selection cutting, $\mathrm{L}=$ low thinning and $\mathrm{C}=$ controls.

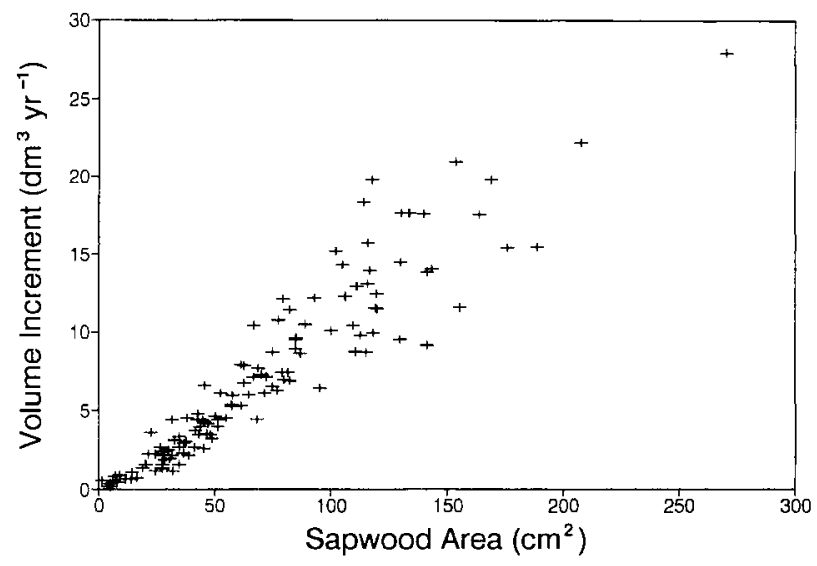

Figure 5. Volume increment in relation to sapwood area (sapwood cross-sectional area at crown base) for Scots pine.

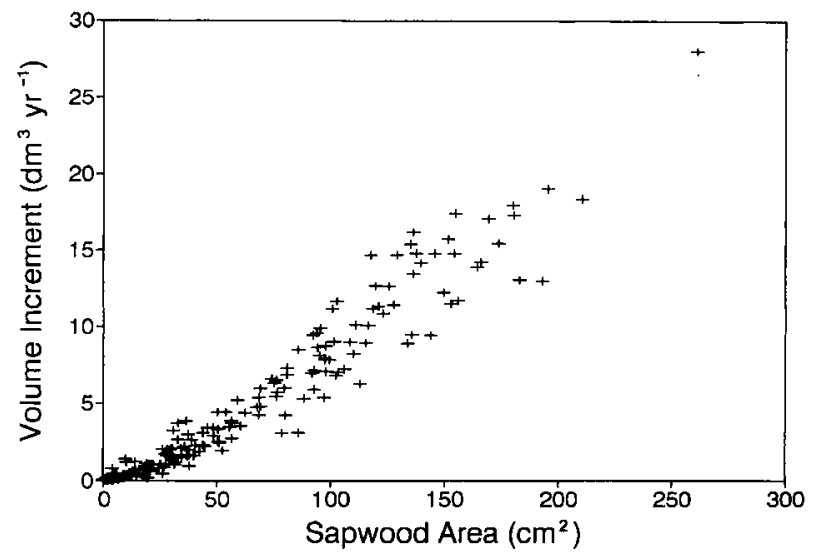

Figure 6. Volume increment in relation to sapwood area (sapwood cross-sectional area at crown base) for Norway spruce.

\subsection{Individual tree dynamics}

Strong relationships were apparent between sapwood cross-sectional area at crown base (sapwood area) and tree increment for both Scots pine and Norway spruce (figures 5 and 6). For Scots pine, a linear model with no constant explained $81 \%$ of variation in volume increment. However, separate equations for the overstory and understory trees (figure 7) were developed for application in a stocking model for multi-strata stands. Equation forms were selected based on analysis of residuals, standard errors and coefficients of determination. Simple linear models were used for the understory and the overstory (figures $7 A, B$ ).

The relationship between tree increment and sapwood area was stronger for Norway spruce than Scots pine (figures 5 and 6). A linear equation for all Norway spruce trees explained $95 \%$ of variation in volume increment with a $\mathrm{S}_{\mathrm{ylx}}$ of $1.3 \mathrm{dm}^{3}$. Separating upper and lower canopy classes for the multi-aged stocking model improved these results (figure 8). A linearized allometric model provided the best fit for the overstory, while a Chapman-Richards growth function was used for the understory. Models for overstory trees had greater slopes than for the understory for both species. 

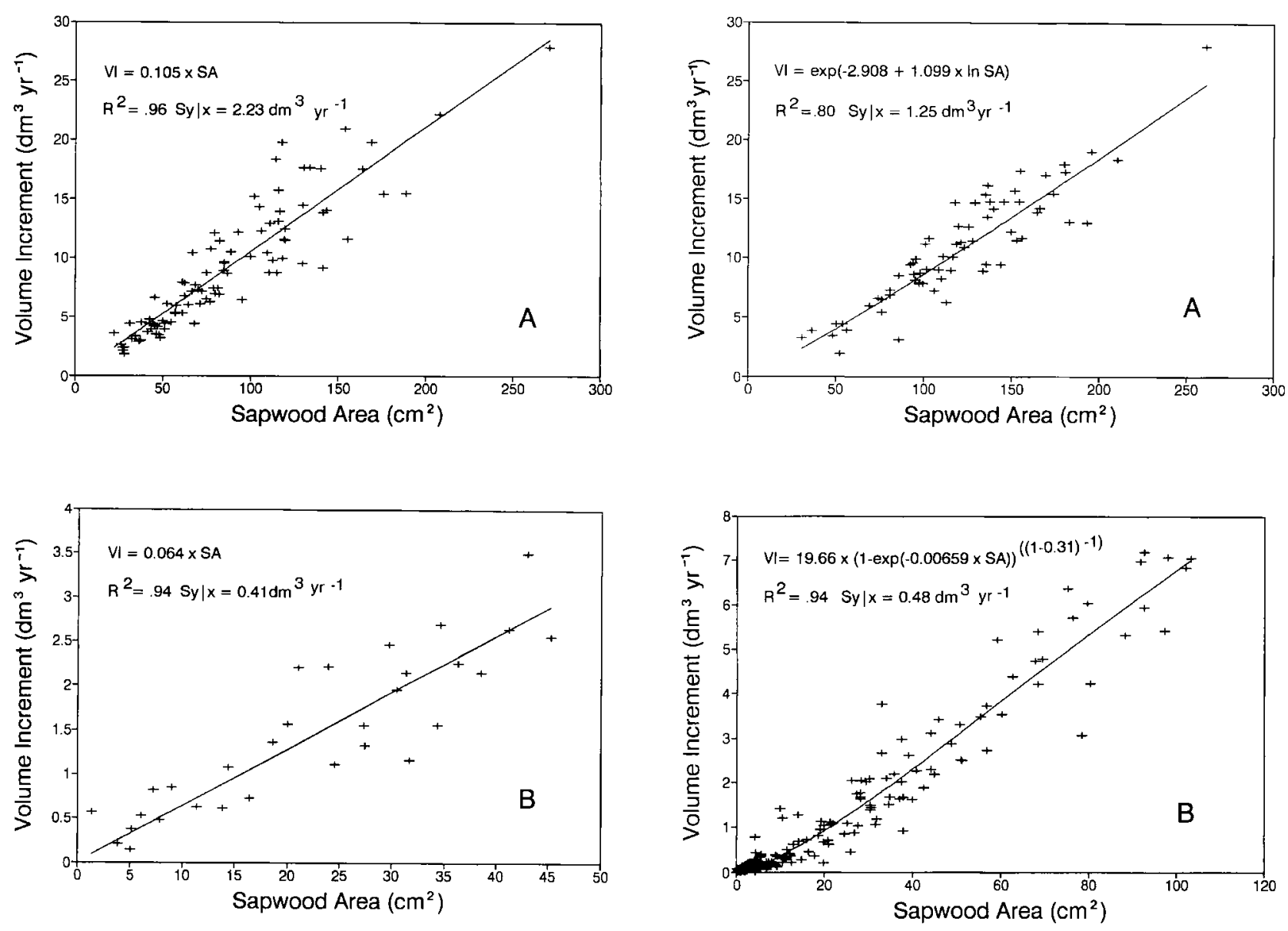

Figure 7. Volume increment in relation to sapwood area by crown class group for $S$ cots pine $(A=$ overstory trees, $\mathrm{B}=$ understory trees).

Figure 8. Volume increment in relation to sapwood area by crown class group for Norway spruce $(A=$ overstory trees, $\mathrm{B}=$ understory trees).

\section{DISCUSSION}

\subsection{Stand-level leaf area dynamics}

LAIs presented in this study should be viewed with caution because of the non-local origin of the leaf area/sapwood coefficients for Norway spruce and the broadleaf species, and the different methodologies used to develop the leaf area/sapwood coefficients for Norway spruce and Scots pine. Nevertheless, the results are consistent with other studies using these species. For example, LAI for pure stands of Scots pine have ranged from 2.4 to 3.1 in Scotland [36], 2.7 in England, 1.5 to 2.0 in central Sweden [32] and 4.5 in central Finland [31]. For Norway spruce, values of 11.5 in southern Sweden [17] and 10.6 in Germany [25] have been reported. Albrekson

et al. [1] reported Norway spruce LAI ranging from 1.6 to 5.5 in a series of fertilizer plots in Sweden. Very few studies have reported LAI for broadleaf species in Scandinavia. Among these, Johansson [6] reported a LAI of 2.3 for young birches in Sweden and Johansson [7] reported LAIs of 0.5 to 2.5 in 20- to 40 -year-old birch stands in Sweden. Nygren and Kellomäki [18] found LAIs ranging from 0.4 to 11.4 in young birch stands in central Finland.

Variations in stand LAI related to species composition are characteristic of species differences in light interception strategies. Species with large amounts of stand LAI intercept larger amounts of radiation than species with lower stand LAI, but they generally use this LAI less efficiently [30]. 
In this study, sample plots varied in species composition from nearly pure Norway spruce to nearly pure Scots pine. These extreme plots were therefore most representative of the potential LAI for pure stands of these two species. The other plots were various mixtures including a relatively large broadleaf component. Since LAI reaches and maintains a relatively constant level in undisturbed stands, these plots provide a base LAI level from which to gauge the potential LAI for these species on similar sites. For example, the Norway spruce LAI of 6.1 observed in plot 54 indicates that pure spruce stands on these sites could support a LAI of approximately 6.0 on similar sites. For Scots pine on similar sites, a LAI of approximately 2.5 appears to represent a maximum.

The relationship between stand volume increment and LAI is also strongly influenced by the structure of each stand. Variations in the arrangement of a constant amount of LAI can lead to dramatic variations in volume increment. For example, O'Hara [20] observed a difference of greater than $40 \%$ in stand increment in paired thinning plots in even-aged coast Douglas fir that received the same thinning treatment and had the same LAI, but different structural arrangements of LAI. Similar patterns were observed in multiaged ponderosa pine (Pinus ponderosa Dougl. ex. Laws.) stands [21]. Results from this study demonstrate the differences in increment resulting from variations in species composition and arrangement of LAI by crown class group (figure $4 A, B)$.

\subsection{Species dynamics}

Although strong relationships between stand volume increment and LAI have been observed for many species, these results rarely have the variability in species composition or treatment as the plots included in this study. Species GSEs from the present study also demonstrated why species composition had a major effect on stand efficiency, but not stand increment. Plots with large proportions of Scots pine had higher stand GSEs than other plots, but since their total LAI was low, stand volume increment was comparable to plots with higher LAI and lower GSE. Norway spruce did not produce volume increment per unit of leaf area as efficiently as the Scots pine, but this species compensated by accumulating a higher LAI and therefore produced a similar total increment. For other combinations of species, differences in GSE and total LAI by species may lead to large differences in stand volume increment with different species compositions.

The species GSEs were relatively constant across all treatments (table $I I$ ). The coefficients of variation for
GSE were 15.8 and $16.7 \%$ for Scots pine and Norway spruce over all 11 plots despite large differences in the mean GSE for these species $\left(8.6\right.$ and $1.7 \mathrm{~m}^{3} \mathrm{~m}^{-2}$ for Scots pine and Norway spruce). This suggests that volume increment may be relatively predictable regardless of treatment history for each species if species LAIs are known.

\subsection{Individual tree leaf area dynamics}

In contrast to the stand level results, strong relationships were apparent between volume increment and sapwood area for individual trees of both Scots pine and Norway spruce in this study. Similar results have been widely reported in the literature $[4,19,21,29,35]$.

Also important to discussions of production ecology of conifers are the fitted equations to these relationships between volume increment and sapwood area. Because leaf area or sapwood area can be assumed to represent the occupied growing space of an individual tree [19, 21 , the relative efficiency with which this growing space is used to produce volume increment has implications for stocking arrangements. For example, if overstory trees were more efficient users of growing space than understory trees, then managers would enhance cubic volume increment by designing. structures which favoured these more efficient trees. GSE can also be determined from the form of the tree increment/leaf area equation. Any non-linearity to this equation will therefore effect the subsequent growing space efficiency relationship.

\subsection{Treatment effects}

Silvicultural treatments, such as thinnings, can be interpreted as redistributions of LAI over the long-term and reductions of LAI over the short-term. This was also apparent in this study where the low thinning treatments had relatively low LAI compared to the untreated controls or the selection treatments. Over the long-term, the LAI in these low thinning treatments would be redistributed on the crop trees to enhance tree growth rates, eventual size and value. The short-term reduction in LAI reduced total stand volume increment and cumulative stand volume as compared to the untreated controls.

The selection treatments represent a management alternative which results in a different distribution of LAI. By removing trees across all size classes, the selection treatments at Vessari resulted in a small relative reduction in LAI, and maintained a higher proportion of LAI in the lower social classes than low thinning. The 
greater LAI in the selection treatments explains their potential for greater short-term volume increment than the low thinnings. This may also explain the greater increment observed in all-sized stands as compared to even-sized stands in Finland [10, 11, 28].

The long-term comparisons of these treatments will, of course, be of great interest. Since the lower social classes produce less volume increment per unit of sapwood area (leaf area) than the upper social classes, the structural arrangement which organizes all LAI into a single canopy stratum would theoretically maximize stand increment. However, it may be possible that LAI can only be maximized in a canopy with a diverse structure. In this case, the selection treatments may produce the greater long-term increments.

The results from this study are insufficient to base any long-term conclusions regarding the relative long-term productivity of different silvicultural treatments. Further studies that examine leaf area efficiencies in stands with a longer history of treatment, and in stands with less variation in species composition would be useful to meet these goals.

Acknowledgements: O'Hara's participation in this project as a visiting scientist at the Parkano Research Station of the Finnish Forest Research Institute was supported by a Michaux grant from the American Philosophical Society, a sabbatical leave from the University of Montana and the Finnish Forest Research Institute. The authors are indebted for the assistance provided by Jari Ilomäki and Aulikki Hamari with data collection and analysis. The assistance of Matti Maltamo with sapwood area at crown base calculations for Scots pine is also appreciated.

\section{REFERENCES}

[1] Albrekson A., Aronsson A., Tomm C.O., The effect of forest fertilization on primary production and nutrient cycling in the forest ecosystem, Silva Fennica 11 (1977) 233-239.

[2] Beadle C.L., Talbot H., Jarvis P.G., Canopy structure and leaf area index in a mature Scots pine forest, Forestry 55 (1982) 105-123.

[3] Cajander A.K., Forest types and their significance, Acta Forestalia Fennica 56 (1949) 1-71.

[4] Gilmore D.W., Seymour R.S., Alternate measures of stem growth efficiency applied to Abies balsamea from four canopy positions in central Maine, USA, For. Ecol. Manage. 84 (1996) 209-218.

[5] Gustavsen H.G., Talousmetsien kasvupaikkaluokittelu valtapituuden avulla. Summary: Site index curves for conifer stands in Finland, Folia Forestalia 454 (1980) 1-31.

[6] Johansson T., Irradiance within canopies of young trees of European aspen (Populus tremula L.) and European birch
(Betula pubescens Ehrh.) in stands of different spacings, For. Ecol. Manage. 28 (1989) 217-236.

[7] Johansson T., Estimation of canopy density and irradiance in 20- to 40-year-old birch stands (Betula pubescens Ehrh. and Betula pendula Roth), Trees 10(4) (1996) 223-230.

[8] Laasasenaho J., Taper curve and volume functions for pine, spruce and birch, Communicationes Instituti Forestalis Fenniae 108, 1982.

[9] Lähde E., Luontaisen kuusivaltaisen taimikon kehitys lehtomaisella kankaalla. Summary: Development of Picea abies-dominated naturally established sapling stand, Folia Forestalia 793, 1992.

[10] Lähde E., Laiho O., Norokorpi Y., Saksa T., Structure and yield of all-sized an even-sized conifer-dominated stands on fertile sites, Ann. Sci. For. 51 (1994) 97-109.

[11] Lähde E., Laiho O., Norokorpi Y., Saksa T., Structure and yield of all-sized and even-sized Scots pine dominated stands, Ann. Sci. For. 51 (1994) 111-120

[12] Long J.N., Smith F.W., Relation between size and density in developing stands: A description and possible mechanisms, For. Ecol. Manage. 7 (1984) 191-206.

[13] Mäkelä A., Virtanen K., Nikinmaa E., The effects of ring width, stem position, and stand density on the relationship between foliage biomass and sapwood area in Scots pine (Pinus sylvestris), Can. J. For. Res. 25 (1995) 970-977.

[14] Margolis H., Oren R., Whitehead D., Kaufmann M.R., Leaf area dynamics of conifer forests, in: Smith W.K., Hinckley T.M. (Eds.), Ecophysiology of Coniferous Forests, Academic Press, San Diego, CA, 1995, pp. 181-224.

[15] Mencuccini M., Grace J., Climate influences the leaf area/sapwood area ratio of Scots pine, Tree Phys. 15 (1995) $1-10$.

[16] Möller C.M., The effect of thinning, age, and site on foliage, increment, and loss of dry matter, J. For. 45 (1947) 393-404.

[17] Nihlgård B., Plant biomass, primary production and distribution of chemical elements in a beech and a planted spruce forest in southern Sweden, Oikos 23 (1972) 69-81.

[18] Nygren M., Kellomäki S., Effect of shading on leaf structure and photosynthesis in young birches, Betula pendula Roth. and B. pubescens Ehrh., For. Ecol. Manage. 7 (1983) 119-132.

[19] O'Hara K.L., Stand structure and growing space efficiency following thinning in an even-aged Douglas fir stand, Can. J. For. Res. 18 (1988) 859-866.

[20] O'Hara K.L., Stand growth efficiency in a Douglas fir thinning trial, Forestry 62 (1989) 409-418.

[21] O'Hara K.L., Dynamics and stocking relationships of multi-aged ponderosa pine stands, For. Sci. 42(4), Monograph 33, 1996.

[22] O'Hara K.L., Valappil N.I., Sapwood/Leaf area prediction equations for multi-aged ponderosa pine stands in western Montana and central Oregon, Can. J. For. Res. 25 (1995) 1553-1557. 
[23] Ojansuu R., Maltamo M., Sapwood and heartwood taper in Scots pine stems, Can. J. For. Res. 25 (1995) 1928-1943.

[24] Oren R., Werk K.S., Schulze E.-D., Relationships between foliage and conducting xylem in Picea abies (L.) Karst., Trees 1 (1986) 61-69.

[25] Oren R., Schulze E.-D., Werk K.S., Meyer J., Schneider V.U., Heilmeier H., Performance of two Picea abies (L.) Karst. stands at different stages of decline. I. Carbon relations and stand growth, Oecologia (Berlin) 75 (1988) 25-37.

[26] Pothier D., Margolis A. Analysis of growth and light interception of balsam fir and white birch saplings following precommercial thinning, Ann. Sci. For. 48 (1991) 123-132.

[27] Roberts S.D., Long J.N., Production efficiency of Abies lasiocarpa: influence of vertical distribution of leaf area, Can. J. For. Res. 22 (1992) 1230-1234.

[28] Saksa T., Lähde E., Laiho O., Norokorpi Y., Growth and yield in structurally diverse and one-sided stands, in: Skovsgaard J.P., Burkhart H.E. (Eds.), Recent Advances in Forest Mensuration and Growth and Yield Research, Danish Forest and Landscape Research Institute, Hørsholm, Denmark, 1995 , pp. 167-174.

[29] Schroeder P.E., McCandish B., Waring R.H., Perry D.A., The relationship of maximum canopy leaf area to forest growth in eastern Washington, Northwest Sci. 56 (1982) $121-130$.
[30] Smith F.W., Long J.N., A comparison of stemwood production in monocultures and mixtures of Pinus contorta var latifolia and Abies lasiocarpa, in: Cannell M.G.R., Malcolm D.C, Robertson P.A. (Eds.), The Ecology of Mixed-Species Stands of Trees, Blackwell Scientific Publications, London, 1992, pp. 87-98

[31] Smolander H., Stenberg P., Response of LAI-2000 estimates to changes in plant surface area index in a Scots pine stand, Tree Phys. 16 (1996) 345-349.

[32] Stenberg P., Linder S., Smolander H., Flower-Ellis J., Performance of the LAI-2000 plant canopy analyzer in estimating leaf area index of some Scots pine stands, Tree Phys. 14 (1994) 981-995.

[33] Tadaki Y., Some discussions of the leaf biomass of forest stands and trees, Tokyo Forest Experiment Station, Bulletin 184, 1966, pp. 135-161.

[34] Waring R.H., Estimating forest growth and efficiency in relation to canopy leaf area, in: MacFadyen A., Ford E.D. (Eds), Advances in Ecological Research, Volume 13, Academic Press, London, 1983, pp. 325-354.

[35] Waring R.H., Thies W.G., Muscato D., Stem growth per unit of leaf area: a measure of tree vigor, For. Sci. 26 (1980) 112-117.

[36] Whitehead D., The estimation of foliage area from sapwood basal area of Scots pine, Forestry 51 (1978) 137-149. 